\title{
Cardiorenal syndrome: Clinical and echocardiographic aspects
}

\section{Síndrome cardiorrenal: aspectos clínicos y ecocardiográficos}

\author{
Paola Alprecht-Quiroz', Byron Zúñiga-Pineda²,3,4, Joffre J. Lara-Terán³, Silvia V. Cáceres-Vinueza ${ }^{4}$, and \\ Yan C. Duarte-Vera ${ }^{4,5,6 *}$ \\ ${ }^{1}$ Department of Internal Medicine, Hospital Luis Vernaza, Guayaquil; ${ }^{2}$ Department of Nephrology, Hospital Luis Vernaza, Guayaquil; ${ }^{3}$ Department \\ of Cardiology, Hospital Juan Tanca Marengo, Guayaquil; ${ }^{4}$ Faculty of Medical Sciences, Universidad de Guayaquil, Guayaquil; ${ }^{5}$ Department of \\ Cardiology, Hospital General Luis Vernaza, Guayaquil; ${ }^{6}$ Department of Research and Teaching, Sociedad Ecuatoriana de Cardiología, Núcleo \\ Guayas. Ecuador
}

\begin{abstract}
Cardiorenal syndrome (CRS) is a disorder in which the heart and kidneys are involved, interacting, and producing a dysfunction between them in an acute or chronic way. There are different clinical phenotypes well identified as "heart and kidney disorders in which acute or chronic dysfunction in one organ induce acute or chronic dysfunction in the other." The high incidence of cardiovascular morbimortality in patients with chronic terminal kidney disease (CKD), especially heart failure (HF), initially causes a myocardial lesion that leads to ventricular remodeling, which induces the activation of compensatory mechanisms, among which the kidney is a fundamental part since it regulates the hydroelectrolytic homeostasis and thus the circulating volume, being this in the dialytic stage more evident. The functional and anatomical changes at cardiovascular level that occurs in these patients are very prevalent and include hemodynamic interactions of the heart and kidneys in HF and the impact of atherosclerotic disease in both organ systems. We also describe diagnostic and therapeutic strategies applicable to CRS, which determine the importance of echocardiography as a useful diagnostic model. Finally, we analyze the possibilities of treatment and remission of cardiac functional alterations with renal transplantation in patients with T-CKD.
\end{abstract}

Key words: Cardiorenal syndrome. Kidney transplant. Echocardiographic aspects. Systolic function. Diastolic function. Left ventricular hypertrophy.

\section{Resumen}

El síndrome cardiorrenal (SCR) es un trastorno en el que intervienen el corazón y los riñones, interactuando y produciendo una disfunción entre ellos en forma aguda o crónica. Existen diferentes fenotipos clínicos bien identificados como "desórdenes del corazón y riñón en los que la disfunción aguda o crónica en un órgano induce la disfunción aguda o crónica del otro". La alta incidencia de morbimortalidad cardiovascular presente en los pacientes con enfermedad renal crónica terminal (ERCT), en especial la insuficiencia cardiaca (IC), origina inicialmente una lesión miocárdica que conlleva remodelamiento ventricular, lo cual induce a la activación de mecanismos compensadores, entre los cuales el riñón es pieza fundamental, ya que regula la homeostasis hidroelectrolítica y así el volumen circulante, siendo esto en la etapa dialítica más evidente. Los cambios funcionales y anatómicos cardiovasculares que se producen en estos pacientes son muy prevalentes e incluyen las

Available online: 02-03-2021
Date of reception: 24-02-2020

Date of acceptance: 21-08-2020 DOI: 10.24875/ACME.M20000156
Arch Cardiol Mex (Eng). 2020;90(4):466-472

www.archivoscardiologia.com 2604-7063 / C 2020 Instituto Nacional de Cardiología Ignacio Chávez. Published by Permanyer. This is an open access article under the CC BY-NC-ND license (http://creativecommons.org/licenses/by-nc-nd/4.0/). 
interacciones hemodinámicas del corazón y los riñones en la insuficiencia cardiaca, y el impacto de la enfermedad aterosclerótica en ambos sistemas de órganos. También describimos estrategias diagnósticas y terapéuticas aplicables al síndrome cardiorrenal, que determinan la importancia de la ecocardiografía como modelo de diagnóstico útil. Finalmente, se analizan las posibilidades de tratamiento y la remisión de las alteraciones funcionales cardiacas con el trasplante renal en los pacientes con ERCT.

Palabras clave: Síndrome cardiorrenal. Trasplante renal. Aspectos ecocardiográficos. Función sistólica. Función diastólica. Hipertrofia ventricular izquierda.

\section{Introduction}

Throughout its evolution, heart disease is a common complication of advanced or end-stage renal disease (ESRD), especially when it interacts with heart failure (HF), and it is the leading cause of death in patients on renal replacement therapy ${ }^{1}$. Alterations in cardiac morphology and function are rather common in individuals with chronic kidney failure, mainly in those who are on dialysis ${ }^{2,3}$. There is enough evidence that demonstrates left ventricular hypertrophy (LVH) regression and improved ventricular function after successful kidney transplant (KT), which constitutes the best therapeutic alternative for ESRD treatment, since it significantly improves life quality and expectancy of the kidney disease patient in comparison with replacement therapy ${ }^{4}$. Echocardiographic evaluation is an essential tool in the assessment, diagnosis, and prognosis of patients with chronic kidney failure, since it is a non-invasive study that is used to evaluate the heart structure and function ${ }^{5}$.

\section{Cardiorenal syndrome (CRS)}

CRS is characterized by a high degree of interactions between the heart and the kidneys ${ }^{6,7}$. It is a state of advanced deregulation between heart and kidneys ${ }^{8}$, which entails compromise of both systemic organs ${ }^{9}$ due to an acute or chronic dysfunction of one of the organs that induce dysfunction of the other ${ }^{10}$, whereby physiological functions in the heart-kidney relationship will be altered, where either of both organs will use a compensation mechanism that will have an important impact on the other organ ${ }^{11}$.

The definition of this syndrome has three particular characteristics that make us understand it:

- Equal relevance between both organs, since often it is unclear where the damage started

- Dysfunction can be acute or chronic, functional. or structural

- CRS has a bidirectional interaction ${ }^{12}$.
These characteristics lead to a vicious cycle that translates into decompensation of the entire circulatory system ${ }^{13}$. There is close communication between the heart and the kidneys through several pathways that include renal perfusion pressure, cardiac filling pressure, and neurohormonal activity, particularly of the sympathetic nervous system, the renin-angiotensin-aldosterone system, and natriuretic peptides ${ }^{14}$.

Based on this concept, chronic kidney disease (CKD) produces heart structural and functional changes such as left ventricular (LV) dilatation, LV systolic and diastolic dysfunction, and LVH, with the latter being the most commonly observed change in patients with $\mathrm{CKD}^{15}$. LVH is the result of multiple factors: high blood pressure, volume overload, chronic uremic environment, and inflammatory, metabolic, and hormonal changes.

This was grouped in five subtypes according to disease acuteness and organs sequential involvement, as described in figure $1^{7-16}$. The goals of this CRS consensual definition were to facilitate a reliable characterization of cardiorenal deregulation clinical presentation for diagnostic and therapeutic purposes, and to rationalize epidemiological studies inclusion criteria, to identify treatment target populations, and to develop new diagnostic tools for diagnosis and management of $\mathrm{CRS}^{16}$.

\section{Cardiovascular events in CKD}

The main cardiovascular events account for almost $50 \%$ of the causes of death in patients with CKD. Cardiovascular mortality is estimated to be twice as high in subjects with Stage 3 CKD (estimated glomerular filtration rate [eGFR] between 30 and $60 \mathrm{~mL} / \mathrm{min}$ ) and 3 times higher at Stage 4 (eGFR between 15 and 30 $\mathrm{mL} / \mathrm{min}$ ), in comparison with the population with normal kidney function. However, patients at any stage from 1 to 4 have a lower degree of cardiovascular compromise in comparison with patients on dialysis. Stage 5 patients who are not on renal replacement therapy showed a similar mortality rate to those on dialysis ${ }^{17}$. 


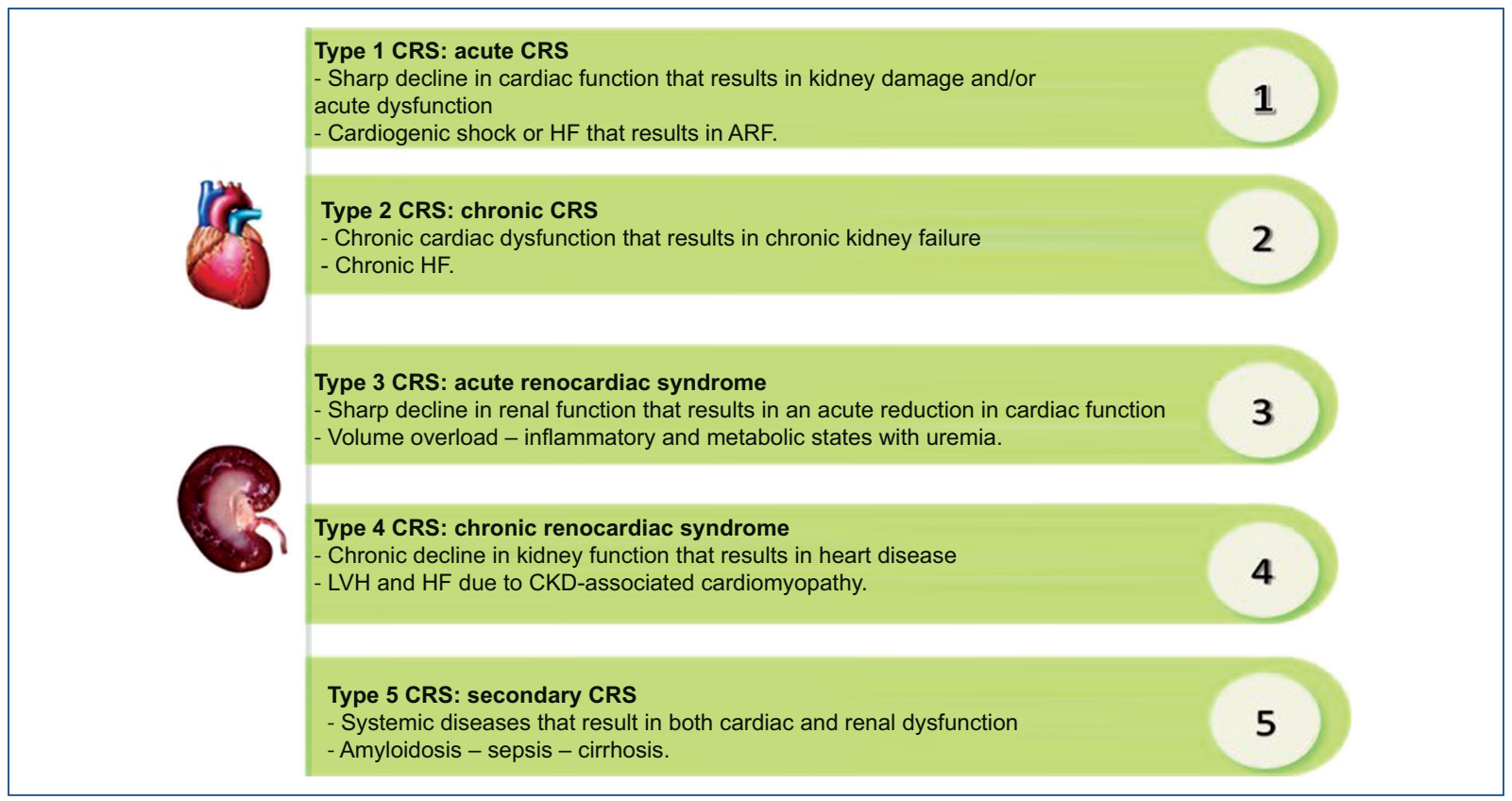

Figure 1. CRS classification (adapted from Pereira-Rodríguez et al., $2017^{7}$ and Rangaswami et al., 201916). CRS: cardiorenal syndrome; ARF: acute renal failure; CKD: chronic kidney disease; LVH: left ventricular hypertrophy.

The prevalence of $\mathrm{LVH}$ is estimated to range between $16 \%$ and $31 \%$ in individuals with eGFR $>30 \mathrm{~mL} / \mathrm{min}$; it increases to $60-75 \%$ before starting renal replacement therapy, and it rises to $90 \%$ after dialysis is started ${ }^{18}$. The prevalence of LV systolic dysfunction varies between $15 \%$ in patients who start hemodialysis treatment and $18 \%$ for those who are on regular dialysis treatment, and it can reach $28 \%$ in those evaluated for transplantation ${ }^{19}$. Figure 2 shows the relationship between HF and chronic kidney failure.

\section{Uremic cardiomyopathy}

The myocardial remodeling that occurs in chronic kidney patients' cardiovascular disease, also called uremic cardiomyopathy, is predominantly secondary to volume and pressure overload (Fig. 3). There is big difference between general population survival and survival of patients with ESRD, due to accumulation of cardiac and vascular pathology. In Foley's epidemiologic study, $5-12 \%$ of individuals of the general population had coronary heart disease and $20 \%$ had ultrasound diagnosed LVH; conversely, of the patients with ESRD who were being started on dialysis, $40 \%$ had coronary heart disease and $75 \%$, or even more, had $\mathrm{LVH}^{20}$. The fact that these figures have been obtained at the beginning of the dialysis program accounts for the importance of what happens before the patient is able to gain access to this procedure.

Among the structural changes, predominantly concentric LVH and valve alterations such as aortic and mitral valve calcification have been observed. As for ventricular function changes, echocardiography suggests higher diastolic $(50 \%)$ than systolic dysfunction $(20 \%)$ in patients on dialysis ${ }^{21}$. Diastolic dysfunction is caused by altered ventricular relaxation and reduced distensibility secondary to myocardial interstitial fibrosis.

LVH is the myocardial abnormality that is predominantly specific of uremic heart disease ${ }^{3}$, and it is caused by LV pressure overload secondary to increased systemic arterial resistance, to blood pressure elevation and reduced distensibility of the great vessels due to aortic calcification, which it is typical in patients with CKD; all these factors result in myocardial cells thickening and LV concentric remodeling together with intracardiac renin-angiotensin system activation; this induces hyperaldosteronemia, which promotes cardiac fibrosis through signals that induce the production of profibrotic growth factors, the vicious cycle of myocardial remodeling ${ }^{3-22}$.

Myocardial hypertrophy induces cell apoptosis and activates metabolic pathways capable of increasing the production of extracellular matrix until fibrosis is reached. Fibrosis leads to a progressive deterioration 


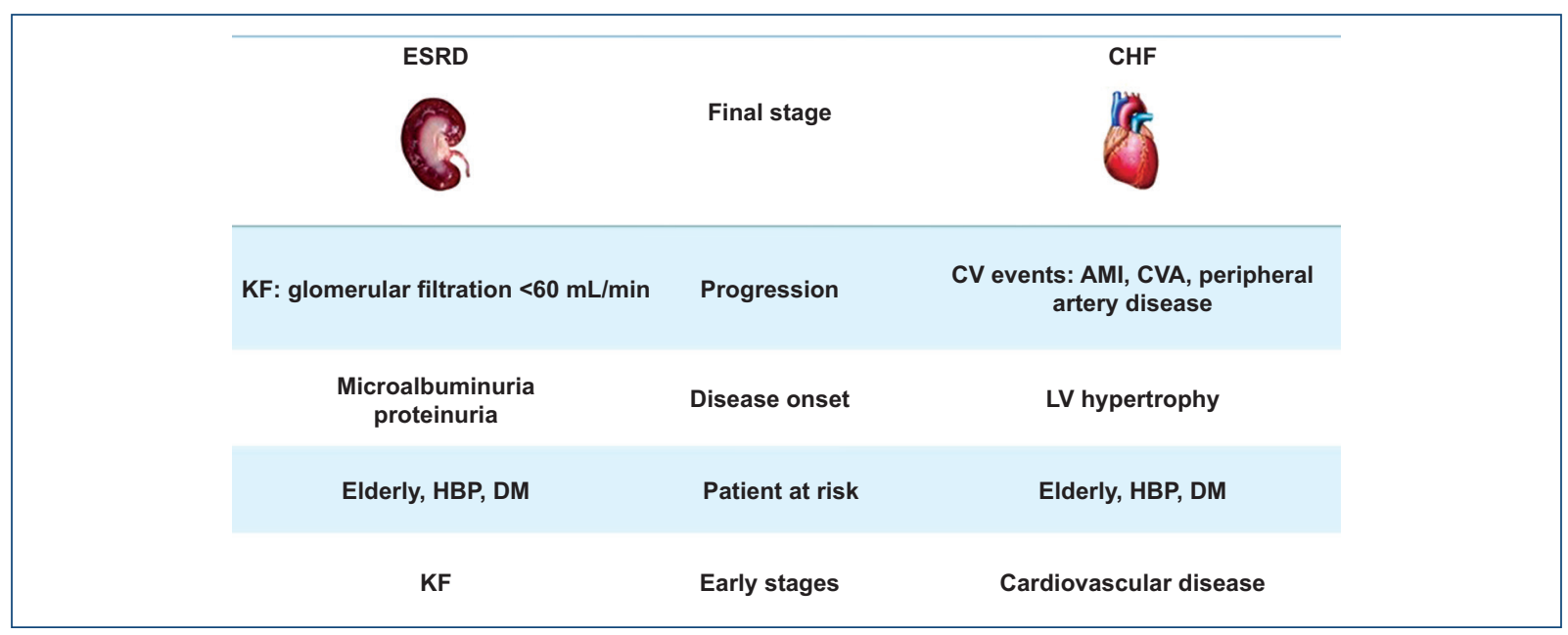

Figure 2. Relationship between heart failure and chronic kidney failure (adapted from Pereira-Rodríguez et al., 20177). KF: kidney failure; HBP: high blood pressure; DM: diabetes mellitus; ESRD: end-stage renal disease; LV: left ventricle; CV: cardiovascular; AMI: acute myocardial infarction; CVA: cerebrovascular accident; CHF: chronic heart failure.

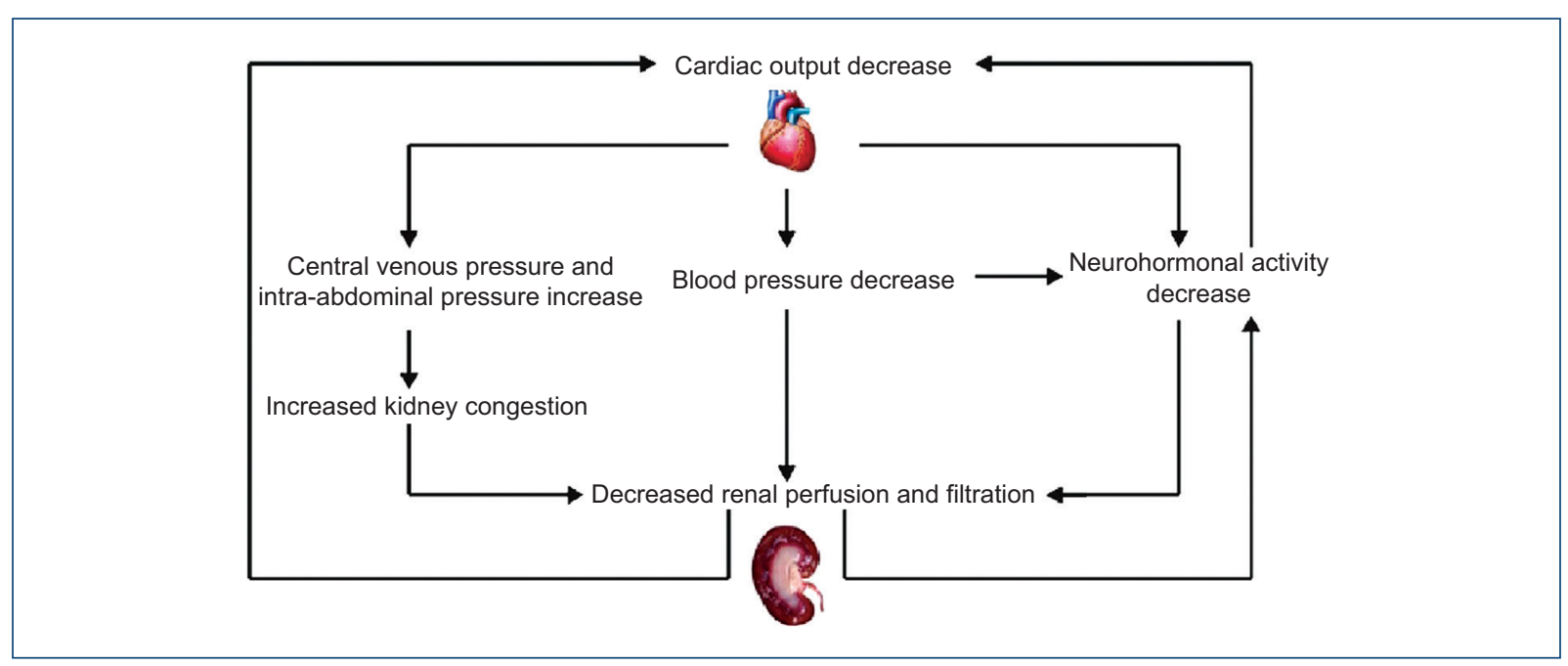

Figure 3. Effect of heart failure on kidney function.

of myocardial wall contractility, systolic and diastolic dysfunction, dilated cardiomyopathy, and congestive $\mathrm{HF}(\mathrm{CHF})$. These changes in the heart structure lead to alterations in cardiac electrophysiology and, hence, to the development of arrhythmias ${ }^{17}$.

LVH is highly predictive of cardiovascular morbidity and mortality, in addition to being quite common among patients with CKD and, in this population, being secondary to multiple factors such as high blood pressure, volume excess, a uremic environment, and different inflammatory, metabolic, and hormonal changes.

Cardiovascular compromise is present in around $80 \%$ of patients on hemodialysis ${ }^{16}$, and $75 \%$ of patients who are started on dialysis have LVH. The present study observed that $84.7 \%$ of the patients developed severe LVH with 3 or more years of dialysis ${ }^{20}$

As for diastolic dysfunction, it is common in CKD patients as a result of LVH and cardiac fibrosis. Similarly, diastolic function has also been shown to improve after transplantation ${ }^{23,24}$.

Volume overload secondary to dialysis arteriovenous shunt, salt and water overload, anemia, coronary ischemic disease, hypertension, and hypoalbuminemia result in myocardial cell lengthening and LV eccentric or asymmetric remodeling or dilatation ${ }^{3}$. 


\section{$\mathrm{KT}$, the therapeutic alternative}

At present, available treatments for the management of ESRD include dialysis and KT. Dialysis modalities include hemodialysis and peritoneal dialysis, which, in turn, includes chronic ambulatory peritoneal dialysis and automated peritoneal dialysis. The selection of the dialysis modality will be influenced by a myriad of considerations to be taken into account, such as availability and convenience, comorbidities, socioeconomic status, patient's home situation, and the capability to tolerate volume changes ${ }^{25}$.

$\mathrm{KT}$ is the treatment of choice for patients with ESRD, thus resulting in better quantity and quality of life, and lower cost for the health system than long-term dialy$\operatorname{sis}^{26,27}$. HF is an important cause of morbidity and mortality in patients with ESRD, with a reported prevalence among patients on dialysis of 12-36 times that of the general population ${ }^{28-30}$. In a historical cohort study with more than 1900 patients enrolled in the US Renal Data System (Dialysis Morbidity and Mortality Study, WAVE 2), the incidence of HF was $71 / 1000$ person-years, and associated mortality 3 years after HF onset was $83 \%^{31}$. De Mattos et al. ${ }^{32}$ demonstrated a strong correlation between reduced ejection fraction (EF) and mortality in a population selected for KT waiting list, with each left ventricular ejection fraction 1-point increase being associated with a $2.5 \%$ decrease in risk-adjusted mortality. Several studies have shown that $\mathrm{KT}$ is the best treatment for patients with ESRD in terms of survival rate increase, reduced complications, and quality of life improvement.

KT should be discussed with all patients with progressive and irreversible chronic disease. Patients who are interested and who do not have contraindications should be referred to a transplantation program when eGFR is below $30 \mathrm{~mL} / \mathrm{min} / 1.73 \mathrm{~m}^{2}$. Given that patients with ESRD have many comorbidities, it is important for them to be carefully evaluated to detect coexisting diseases that might put perioperative management and post-transplant survival at risk.

In a systematic review of 110 studies that included 1,961,904 patients with kidney failure, KT was associated with a lower risk of mortality and cardiovascular events, as well as to a better quality of life in comparison with chronic dialysis treatment. The results were consistent for the different dialysis modalities, for transplantation from both living and cadaveric donor, and between countries with different health-care systems ${ }^{33}$.

In 2016, a study carried out in Korea over a 4-year period demonstrated that those patients on dialysis who underwent KT showed a significant improvement in overall survival and cardiovascular results in comparison with those who remained on dialysis ${ }^{34}$.

Even a study conducted by Santos et al. reported that patients with CKD of uncommon causes, such as hemolytic uremic syndrome or glomerulonephritis, had better 5-year survival than diabetic patients on dialysis, in addition to higher rates of transplantation than diabetic and hypertensive patients ${ }^{35}$.

These results confirm that $\mathrm{KT}$ is the ideal treatment for chronic kidney failure and justify current attempts to increase the number of patients who benefit from KT all over the world.

\section{Role of echocardiogram in cardiovascular assessment}

Doppler echocardiography is a non-invasive, inexpensive, and widely available technique for evaluating cardiac structure and function by bringing together several ultrasound techniques in a single examination, although it is prone to interobserver variability ${ }^{36}$.

Cardiovascular disease is a broad and heterogeneous entity, with LVH being common in KT candidates, along with LV systolic and diastolic dysfunction, heart valve diseases, and coronary artery disease. Transthoracic echocardiography is usually sufficient to detect significant LVH and LV enlargement, ventricular function, abnormalities in other cardiac chambers, valve abnormalities including mitral and aortic stenosis, and pulmonary hypertension. It is important to remember that echocardiography should be performed only after having reached dry weight and without clinical evidence of CHF.

The presence of pulmonary hypertension is associated with adverse post-transplant outcomes with regard to both graft function and patient survival. The finding of pulmonary hypertension by echocardiography may, in turn, lead to further investigations such as sleep studies and right heart catheterization.

In the case of screening for coronary artery disease in chronic kidney patients with a history of hypertension or diabetes, detecting decreased flow of the coronary sinus by echocardiography at rest has high sensitivity and specificity in the diagnosis of ischemic heart disease ${ }^{37}$.

\section{Kidney transplantation and cardiac remodeling}

$\mathrm{KT}$ has undergone great advances in recent years and has become the treatment of choice for patients 


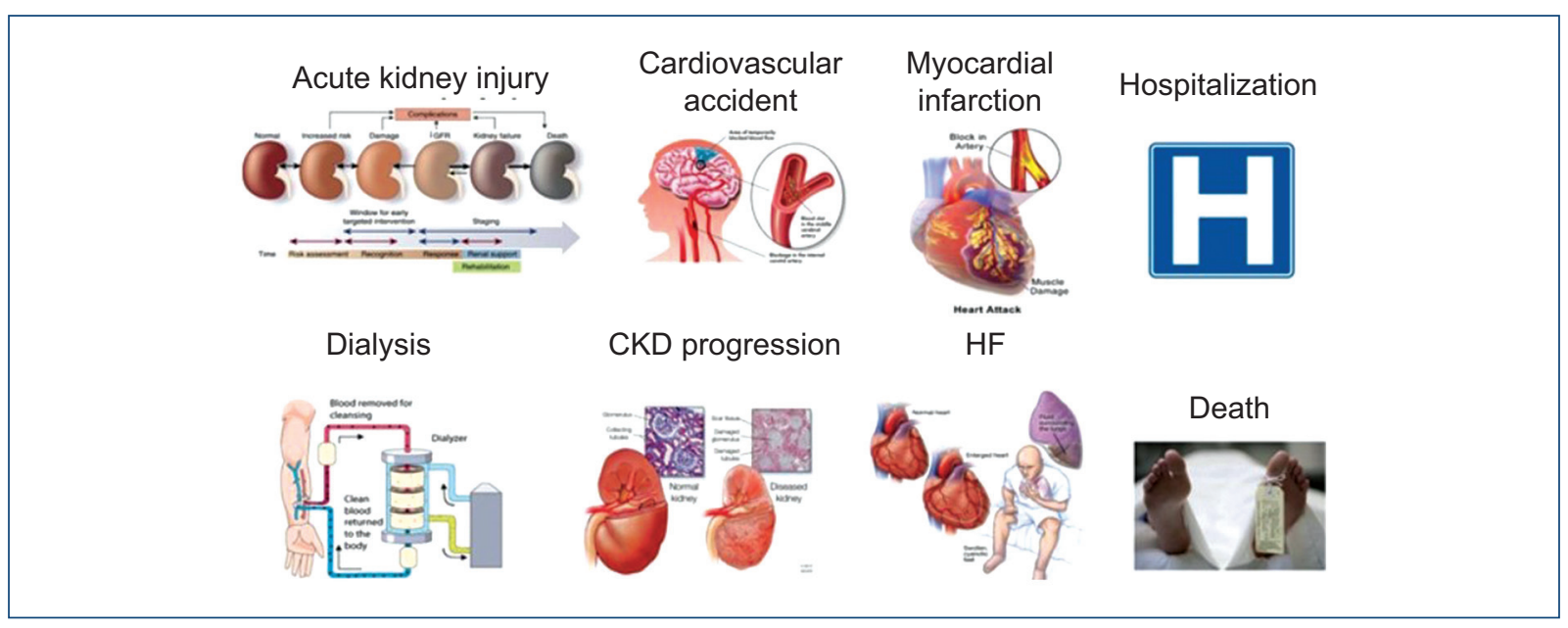

Figure 4. Summary of the main renal and cardiovascular adverse events as a novel clinical endpoint in cardiorenal trials (reprinted with permission from Ronco et al., 201739. Copyright () 2017, S. Karger AG, Basel).

with ESRD, significantly improving life quality and expectancy of these patients, in comparison with permanent renal replacement therapy ${ }^{38}$.

With KT, an adequate GFR is achieved, which corrects blood volume and reduces uremic toxins. Successful KT has been shown to be associated with significant improvements in LV mass index, ventricular function, and valve regurgitation after KT.

This both structural and functional reverse remodeling of the heart plays a critical role in cardiovascular mortality. Thus, $10 \%$ decrease in the left ventricular mass translates into $28 \%$ reduction in the risk of cardiovascular mortality ${ }^{17}$.

In a study carried out in 767 patients who underwent a transthoracic echocardiogram before transplantation, at 1 week, at 1 year, and 5 years later, LVH (defined as a mass index $>115 \mathrm{~g} / \mathrm{m}^{2}$ for men and $95 \mathrm{~g} / \mathrm{m}^{2}$ for women) was shown to occur in $71 \%$ of patients with CKD before transplantation. The prevalence of $\mathrm{LVH}$ decreases from $71 \%$ to $66 \%$ at 1 year and to $57 \%$ at 5 years of transplantation ${ }^{28}$. In addition, the ventricular mass index decrease was shown to be $9.2 \mathrm{~g} / \mathrm{m}^{2}$ at 1 year and $19.1 \mathrm{~g} / \mathrm{m}^{2}$ at 5 years post-transplantation.

We consider supporting the need for a dedicated interdisciplinary cardiorenal team to spearhead early identification of patients with decompensated CRS and jointly manage appropriate clinical interventions at inpatient and outpatient settings ${ }^{39}$.

We trust in an educational proposal to understand CRS, where cardiologists, when facing major cardiovascular events such as HF, myocardial infarction, or cerebrovascular accident, take care of kidney integrity and function; and, on the other hand, where nephrologists have a perception and understanding of acute renal failure and ESRD as multipliers of cardiovascular risk. We need a new generation of cardiorenal physicians with a cutting-edge approach to the detection, diagnosis, prognosis, and management of CRS (Fig. 4) ${ }^{39}$.

\section{Conclusions}

CRS is characterized by a high degree of interactions between the heart and kidneys. This close relationship occurs through atherosclerotic and hemodynamic factors, uremia, anemia, protein imbalance, and genetic factors. Its diagnosis is based both on laboratory data and diagnostic imaging methods such as echocardiography.

There is a critical need for guidelines and better clinical practice models from the leading cardiology and nephrology professional societies, specifically oriented to cardiorenal medicine outcomes and to the funding of research in both specialties to focus on the needs of future therapies.

KT would be a valid therapeutic alternative to reduce the elevated rates of cardiovascular morbidity and mortality in this population.

\section{Acknowledgments}

The authors express their gratitude to the Organ and Tissue Transplantation Unit of the Luis Vernaza Hospital, to the authorities of the Faculty of Medical Sciences of the University of Guayaquil, the Board of Directors of the Ecuadorian Society of Cardiology (Núcleo Guayas, Ecuador) and to Dr. Alfonso Tafur Briones, Dr. Daniel Tettamanti Miranda, Yan C. Duarte Cáceres, 
and Alejandro A. Flor Márquez for their collaboration in this manuscript.

\section{Funding}

This research has not received any specific grant from agencies of the public, commercial, or non-profit sectors.

\section{Conflicts of Interest}

The authors declare that they have no conflicts of interest.

\section{Ethical disclosures}

Protection of human and animal subjects. The authors declare that no experiments were performed on humans or animals for this research.

Confidentiality of data. The authors declare that no patient data appear in this article.

Right to privacy and informed consent. The authors declare that no patient data appear in this article.

\section{References}

1. Ali A, Macphee I, Kaski JC, Banerjee D. Cardiac and vascular changes with kidney transplantation. Indian J Nephron. 2016;26(1):1-9.

2. An JN, Kim YH, Park JB, Hwang JH, Yoo KD, Park JY, et al. The reciprocal interaction between LV remodelling and allograft outcomes in kidney transplant recipients. Heart. 2015;101(22):1826-33.

3. Ardhanari S, Alpert MA, Aggarwal K. Cardiovascular disease in chronic kidney disease: Risk factors, pathogenesis, and prevention. Adv Perit Dial. 2014;30:40-53

4. Hawwa N, Shrestha K, Hammadah M, Yeo PSD, Fatica R, Tang WHW Reverse remodeling and prognosis following kidney transplantation in contemporary patients with cardiac dysfunction. J Am Coll Cardiol. 2015;66(16):1779-87.

5. Lang RM, Badano LP, Mor-Avi V, Afilalo J, Armstrong A, Ernande L, et al. Recommendations for cardiac chamber quantifications by echocardiography and The European Association of Cardiovascular Imagining. J Am Soc Echocardiogr. 2015;28(1):1-39.e14

6. Barros A. Síndrome cardio-renal. Ciencia actual. 2012;2:44-52.

7. Pereira-Rodríguez JE, Boada-Morales L, Niño-Serrato DR, Caballero-Chavarro M, Rincón-Gonzales G, Jaimes-Martín T, et al. Síndrome cardiorrenal Rev Colomb Cardiol. 2017;24(6):602-13.

8. Lobo L, de la Serna F. Síndrome cardiorrenal. Rev Fed Arg Cardiol. 2013;2:88-95

9. J. Pérez, B. Cuevas. Síndrome cardiorrenal. Guías S.E.N. Nefrología. 2008;3:29-32.

10. Dizeo C, Chirino A, Franchi V, Álvarez S, Forcinito D, Trejo G, et al. Síndrome cardiorrenal como predictor de mala evolución intrahospitalaria en pacientes añosos internados con insuficiencia cardiaca. Insuficiencia cardiaca. 2012;7:102-8.

11. Barrio L, Fernández G. Trastornos del agua en el síndrome cardiorrenal. Nefrologia. 2011;2:29-34.

12. Echazarreta D. Insuficiencia cardiaca y síndrome cardiorrenal. Rev Insuf Card. 2010;5:92-6.

13. Suris B, Herrera I, Monteagudo A, Tan I. Síndrome cardiorrenal. AMC 2014;18.
14. Valle J, Bolaños C. Síndrome cardiorrenal. Rev Med Costa Rica Centroam. 2016;:LXXIII:151-6.

15. Hewing B, Dehn AM, Staeck O, Knebel F, Spethmann S, Stangl K, et al. Improved left ventricular structure and function after successful kidney transplantation. Kidney Blood Press Res. 2016;41(5):701-9.

16. Rangaswami J, Bhalla V, Blair JEA, Chang TI, Costa S, Lentine KL, et al. Cardiorenal syndrome: Classification, pathophysiology, diagnosis, and treatment strategies: A scientific statement from the American Heart Association. Circulation. 2019;139:e840-e878.

17. Di Lullo L, Gorini A, Russo D, Santoboni A, Ronco C. Left ventricular hypertrophy in chronic kidney disease patients: From pathophysiology to treatment. Cardiorrenal Med. 2015;5:254-66.

18. Orozco R. Enfermedad cardiovascular en la enfermedad renal crónica. Rev Med Clin Condes. 2015;26(2):142-55

19. Dounousi E, Mitsis M, Naka KK, Pappas C, Lakkas L, Harisis C, et al. Differences in cardiac structure assessed by echocardiography between renal transplant recipients and chronic kidney disease patients. Transplant Proc. 2014;46:3194-8.

20. Foley RN, Curtis BM, Randell EW, Parfrey PS. Left ventricular hypertrophy in new hemodialysis patients without symptomatic cardiac disease. Clin J Am Soc Nephrol. 2010;5(5):805-13.

21. Singh S. Cardiovascular disease in chronic kidney disease. Clinical Queries: Nephrology. 2014;1-10. doi: 10.1016/j.cqn.2014.03.006.

22. Flores Cubías MC, Ramos González HL, Cairo Sáez CG. Cambios ecocardiográficos en los pacientes trasplantados renales. Rev Cubana Cardiol Cir Cardiovasc. 2014;20(1).

23. Souza FL, Bezerra KB, Sousa AR, Ferreira TC, Oliveira MI, Martins GP, et al. Study of echocardiographic alterations in the first six months after kidney transplantation. Arq Bras Cardiol. 2012;98:505-13.

24. Souza FL, Monteiro Junior Fd, Salgado Filho N. Effects of kidney transplantation on cardiac morphology and function. J Bras Nefrol. 2012;34(1):94-100.

25. Devoe DJ, Wong B, James MT, Ravani P, Oliver MJ, Barnieh L, et al. Patient education and peritoneal dialysis modality selection: A Systematic review and meta-analysis. Am J Kidney Dis. 2016;68:422.

26. Axelrod DA, Schnitzler MA, Xiao H, Irish W, Tuttle-Newhall E, Chang SH, et al. An economic assessment of contemporary kidney transplant practice. Am J Transplant. 2018;18:1168-76.

27. Schnitzler MA, Skeans MA, Axelrod DA, Lentine KL, Randall HB, Snyder JJ, et al. OPTN/SRTR 2016 annual data report: economics. Am J Transplant. 2018;18(suppl 1):464-503.

28. Harnett JD, Foley RN, Kent GM, Barre PE, Murray D, Parfrey PS. Congestive heart failure in dialysis patients: prevalence, incidence, prognosis and risk factors. Kidney Int. 1995;47:884-90.

29. Stack AG, Bloembergen WE. A cross-sectional study of the prevalence and clinical correlates of congestive heart failure among incident US dialysis patients. Am J Kidney Dis. 2001;38:992-1000.

30. US Renal Data System. 2017 USRDS Annual Data Report: Epidemiology of Kidney Disease in the United States. Bethesda, MD: National Institute of Health, National Institute of Diabetes and Digestive and Kidney Diseases; 2017.

31. Trespalacios FC, Taylor AJ, Agodoa LY, Bakris GL, Abbott KC. Heart failure as a cause for hospitalization in chronic dialysis patients. Am J Kidney Dis. 2003;41:1267-77.

32. de Mattos AM, Siedlecki A, Gaston RS, Perry GJ, Julian BA, Kew CE, et al. Systolic dysfunction portends increased mortality among those waiting for renal transplant.J Am Soc Nephrol. 2008;19:1191-6.

33. Tonelli M, Wiebe N, Knoll G, Bello A, Browne S, Jadhav D, et al. Systematic review: Kidney transplantation compared with dialysis in clinically relevant outcomes. Am J Transplant. 2011;11(10):2093-109.

34. Yoo KD, Kim CT, Kim MH, Noh J, Kim G, Kim H, et al. Superior outcomes of kidney transplantation compared with dialysis: An optimal matched analysis of a national population-based cohort study between 2005 and 2008 in Korea. Medicine. 2016;95(33):e4352.

35. Santos AH Jr, Casey MJ, Wen X, Zendejas I, Rehman S, Womer KL, et al. Survival with dialysis versus kidney transplantation in adult hemolytic uremic syndrome patients: A fifteen-year study of the waiting list. Transplantation. 2015;99(12):2608-16.

36. Hung MJ. LV remodelling after renal transplantation: future directions. Heart. 2015;101:1776-7.

37. Palepu S, Prasad GVR. Screening for cardiovascular disease before kidney transplantation. World J Transplant. 2015;5(4):276-86.

38. Katz SD, Parikh CR. Reverse left ventricular remodeling after kidney transplantation. J Am Coll Cardiol. 2015;66(16):1788-90.

39. Ronco C, Ronco F, McCullough PA. A call to action to develop integrated curricula in cardiorenal medicine. Blood Purif. 2017;44:251-9. 